Інноватика у вихованні. Випуск 12. 2020.

УДК 378.041:811.111:004

DOI: $\underline{10.35619 / \text { iiu.v1i12.288 }}$

Дмітренко Наталя

кандидат педагогічних наук, доцент, доцент кафедри методики навчання іноземних мов Вінницького державного педагогічного університету імені Михайла Коцюбинського,

м. Вінниця, Україна

ORCID: 0000-0002-3556-0003

e-mail: nataliadmitrenko0302@gmail.com

\title{
ЕКСПЕРИМЕНТАЛЬНА ПЕРЕВІРКА ЕФЕКТИВНОСТІ МЕТОДИКИ АВТОНОМНОГО НАВЧАННЯ ПРОФЕСІЙНО ОРІЕНТОВАНОГО АНГЛОМОВНОГО СПІЛКУВАННЯ МАЙБУТНІХ УЧИТЕЛІВ МАТЕМАТИКИ
}

\begin{abstract}
Анотація. Стаття присвячена проблемі експериментальної перевірки ефективності методики автономного навчання професійно орієнтованого англомовного спілкування майбутніх учителів математики. У статті описані етапи експериментального навчання, а саме: підготовчий етап, етап реалізації та результативний етап; визначенні мета, завдання та гіпотеза експериментального навчання; сформульовані варійована і неварійовані умови експериментального навчання. Варійованою умовою експериментального навчання $є$ послідовність етапів у процесі застосування двох експліцитних моделей навчання стратегій на основі інструкцій «зверху-вниз» і «знизу-вверх» в розробленій методичній системі автономного навчання професійно орієнтованого англомовного спілкування майбутніх учителів математики. Порівняльний аналіз отриманих результатів свідчать про наявний приріст у всіх експериментальних групах, що підтверджує припущення про доцільність комбінування двох варіантів експліцитних моделей на основі інструкцій «зверху-вниз» i «знизу-вверх». Аналіз результатів післяекспериментального зрізу засвідчує сформованість професійно орієнтованої англомовної комунікативної компетентності на рівні володіння мовою В2, а також суттєвий приріст у знаннях, навичках і вміннях учасників експериментального навчання щодо рівня компетентності в автономному навчанні й рівня володіння стратегіями вивчення іноземної мови, що підтверджує робочу гіпотезу експериментального навчання, а, отже, й ефективність розробленої методики автономного навчання професійно орієнтованого англомовного спілкування майбутніх учителів математики.

Ключові слова: автономне навчання, професійно орієнтоване англомовне спілкування, майбутні вчителі математики, експериментальне навчання, варійована умова.
\end{abstract}

Постановка проблеми. Проблема реалізації автономного навчання професійно орієнтованого англомовного спілкування майбутніх учителів математики постала на теренах української науки у зв'язку з необхідністю підготовки нової генерації педагогів, які будуть вільно володіти не лише професійно орієнтованим спілкуванням, а й активно здійснювати іншомовну міжкультурну комунікацію. Автономне навчання створює платформу для

(C) Дмітренко Н., 2020 
ефективної організації і планування навчального процесу та $є$ дидактичною моделлю, у якій створюються необхідні умови для формування автономії студента. Це сприятиме ефективнішому навчанню професійно орієнтованого англомовного спілкування, оскільки автономне навчання мотивує і стимулює студентів до активної, свідомої навчальної діяльності, посилює їхню ініціативність і відповідальність. Розроблена авторська методика автономного навчання професійно орієнтованого англомовного спілкування майбутніх учителів математики потребує експериментальної перевірки, ефективність якої сприятиме поширенню реалізації автономного навчання в закладах вищої освіти України.

Аналіз останніх досліджень 3 проблеми. Методичний експеримент як спосіб з'ясування ефективності педагогічних прийомів через їхнє порівняння, виявлення сильних і слабких сторін різних методичних систем і критеріїв оцінки знань $є$ одним із факторів розвитку методики навчання іноземних мов (Акопова, \& Пшегусова, 2012). Дослідження П. Гурвича, М. Ляховицького, М. Скаткіна, Е. Штульмана грунтуються на переконанні, що стан будь-якої науки залежить від рівня розробленості теоретичних положень, а також від точності результатів проведених експериментальних досліджень. Експеримент забезпечує можливість доведення або спростування наукових припущень, виявлення нових, раніше невідомих явищ і процесів, вивчення й оцінювання не тільки тих, які вже існують, але й тих, які можуть і повинні існувати (Проскурина, 2015, с. 454). Водночас, на думку Е. Штульмана, експеримент дає змогу встановлювати причинно-наслідкові закономірності розумової праці тих, хто навчається, методики викладання іноземних мов, організації навчально-виховного процесу (Штульман, 1976, с. 56).

Мета статті - описати і проаналізувати результати експериментальної перевірки ефективності автономного навчання професійно орієнтованого англомовного спілкування майбутніх учителів математики.

Виклад основного матеріалу дослідження. Для успішної організації експериментального навчання майбутніх учителів математики автономного навчання професійно орієнтованого англомовного спілкування на основі розробленої методичної системи необхідним є повне володіння матеріалом, що досліджується, а також виділення етапів експериментального автономного навчання професійно орієнтованого англомовного спілкування майбутніх учителів математики: підготовчий етап; етап реалізації (здійснення експериментального навчання); результативний етап (аналіз та інтерпретація результатів).

Кожен із цих етапів експериментального навчання має свою організаційну і змістову специфіку й потребує характеристики роботи, яка була проведена на кожному з етапів.

У період nidzотовчого emany було здійснено прогнозування і планування процесу всього експериментального навчання: визначено мету й завдання, сформульовано гіпотезу, сформовано експериментальні групи, визначено зміст експериментального навчання, виділено критерії оцінювання, методи статистичного опрацювання результатів експериментального навчання, проведення діагностичного анкетування.

У 2015-16 н. р. 3 метою виявлення стану розробленості проблеми автономного навчання професійно орієнтованого англомовного спілкування майбутніх учителів математики було проведено діагностичне анкетування 
студентів-першокурсників математичних спеціальностей чотирьох українських педагогічних університетів. Результати проведеного анкетування, що засвідчили невисокий рівень обізнаності й володіння навчальною автономією в цілому та навчальними стратегіями зокрема, стали поштовхом до розробки методичної системи автономного навчання професійно орієнтованого англомовного спілкування майбутніх учителів математики, яка враховувала б сучасні положення методичної науки й передбачала б використання сучасних технологій навчання.

Метою експериментального дослідження є перевірка ефективності методики автономного навчання професійно орієнтованого англомовного спілкування майбутніх учителів математики. Для реалізації поставленої мети визначено перелік завдань, які потребують розв'язання у процесі експериментального навчання, а саме: організувати проведення експериментального навчання й підготувати навчальні матеріали для його проведення; здійснити діагностичне опитування майбутніх учителів математики та їхніх викладачів 3 метою визначення рівня обізнаності щодо питання автономного навчання; провести вхідний зріз для визначення наявного рівня навчальних досягнень сформованої професійно орієнтованої англомовної мовленнєвої компетентності, а також рівнів компетентності в автономному навчанні й володінні стратегіями вивчення мови до початку експериментального навчання; здійснити експериментальне навчання відповідно до запропонованої методики автономного навчання професійно орієнтованого англомовного спілкування; провести вихідний зріз для визначення досягнутого рівня сформованості компетентності в автономному навчанні професійно орієнтованого англомовного спілкування майбутніх учителів математики в кінці експериментального навчання; перевірити достовірність отриманих даних за допомогою методів математичної статистики; проаналізувати та порівняти результати вхідного й вихідного зрізів; сформувати висновки щодо ефективності запропонованої методики автономного навчання професійно орієнтованого англомовного спілкування та надати рекомендації 3 впровадження розробленої методики.

У якості гіпотези висунено припущення про те, що високий рівень сформованості компетентності в автономному професійно орієнтованому англомовному спілкуванні майбутніх учителів математики буде досягнуто, якщо здійснювати:

1) підготовку студентів до формування компетентності в автономному навчанні, яка охоплює: діагностику студентів на визначення рівня компетентності в автономному навчанні, рівня володіння стратегіями навчання у вивченні мови, індивідуального навчального стилю, мотивації, рівня володіння англомовною мовленнєвою компетентністю; корекцію й розвиток умінь автономної навчальної діяльності та розширення спектру навчальних стратегій; самостійність студентів, виражену у визначенні цілей і завдань курсу самим студентом, у виборі стратегій і прийомів, яким він надає перевагу; виховання у студентів почуття відповідальності, здатності до самооцінки й самоконтролю, формування вмінь організувати свою роботу у процесі навчання в цілому;

2) забезпечення педагогічного супроводу, який передбачає cyб' $\mathrm{ckm}$ суб'єктну взаємодію викладача i студента, спрямовану на досягнення навчальних цілей, і дає змогу студентам оволодіти конкретними знаннями, навичками і уміннями, підвищити рівень автономності й усвідомити смисл і значення виконуваних навчальних дій; 
3) створення ефективного навчального професійно орієнтованого середовища, яке сприяє самовизначенню, самореалізації й саморозвитку студентів; містить матеріальне, методичне, технічне забезпечення організації автономного навчання професійно орієнтованого англомовного спілкування.

До неварійованих умов експериментального навчання віднесено:

склад учасників експериментального навчання (кількість груп і студентів у групах): ЕГ1 (14 осіб), ЕГ2 (15 осіб), ЕГ3 (14 осіб), ЕГ4 (15 осіб);

об'єкти контролю, критерії оцінювання відповідей студентів, зміст перед- i післяекспериментальних зрізів;

вихідний рівень сформованості компетентності в автономному професійно орієнтованому англомовному спілкуванні;

реалізацію експериментального навчання в усіх групах тим самим викладачем, який є автором методики;

кількість годин на практичні аудиторні заняття та самостійну роботу студентів (загальна кількість - 330 годин);

тривалість експериментального навчання - 1-4 семестри;

однаковий навчальний матеріал для формування компетентності в автономному професійно орієнтованому англомовному спілкуванні майбутніх учителів математики.

Варійованою умовою експериментального навчання $є$ послідовність етапів у процесі застосування двох експліцитних моделей навчання стратегій на основі інструкцій «зверху-вниз» і «знизу-вверх» в розробленій методичній системі автономного навчання професійно орієнтованого англомовного спілкування майбутніх учителів математики.

Порівнюючи модель «зверху-вниз» із моделлю «знизу-вверх», зазначимо, що обидві моделі походять із конструктивістських i соціокультурних теорій навчання. Мінімалізм моделі «зверху-вниз» дає змогу викладачам застосовувати iï без особливої підготовки через піi просте імплементування. Викладачі, які не обізнані зі стратегічними інструкціями, вважають корисними й доречними іiі прості і зрозумілі інструкції, водночас, модель не забезпечує таким викладачам упевненості у правильному використанні стратегічних інструкцій під час роботи зі студентами. Натомість модель «знизу-вверх» не вимагає теоретичної підготовки викладача в саморегулюванні й навчанні стратегій, але потребує практичного досвіду і гнучкості в контекстуалізації, а також індивідуального підходу до виконання кожного завдання й налаштування інструментування необхідних фонових знань відповідно до можливостей і рівня знань студентів групи.

Було визначено, що в умовах експериментального навчання групи ЕГ1 і ЕГ2 навчатимуться за моделлю «зверху-вниз» (варіант 1), а групи ЕГЗ і ЕГ4 за моделлю «знизу-вверх» (варіант 2).

Методичний експеримент був проведений у 2016-2019 роках у Вінницькому державному педагогічному університеті імені Михайла Коцюбинського. Експериментальне навчання здійснювалося без спеціального відбору студентів, у стандартних умовах звичайного навчального процесу в підгрупах 3 14-15 студентів спеціальності 014.04 Середня освіта (Математика), 111 (Математика) протягом чотирьох семестрів вивчення дисципліни «Іноземна мова для професійного спілкування (англійська)». У процесі експериментального навчання всі студенти експериментальних груп працювали за одними 
навчальними матеріалами, зрізи знань усіх студентів були оцінені за однаковими критеріями.

Отже, відповідно до класифікації П. Гурвича, експериментальне навчання визначено як природне (реалізоване у звичних для студентів умовах), відкрите (не заперечувало можливість певних змін під час проведення експерименту), вертикально-горизонтальне, де по вертикалі здійснено порівняння рівня сформованості компетентності в автономному професійно орієнтованому англомовному спілкуванні до та після експерименту, а по горизонталі ефективності реалізації застосованих експліцитних моделей навчання стратегій на основі інструкцій «зверху-вниз» та «знизу-вверх» (Гурвич, 1980, с. 39).

Метою етаny реалізації експериментального дослідження була передбачена актуалізація ідей, закладених у гіпотезі й перенесених на підготовлені матеріали експерименту.

На основі підрахунку середніх показників кількості балів передекспериментального, проміжного й післяекспериментального зрізів за видами мовленнєвої діяльності в чотирьох ЕГ, було обчислено середні коефіцієнти навченості за формулою В. Беспалька в чотирьох ЕГ:

$$
\mathrm{K}=\mathrm{Q}: \mathrm{N},(1)
$$
балів.

де $\mathrm{Q}$ - кількість отриманих балів, а $\mathrm{N}$ - максимально можлива кількість

Рівень навченості вважається задовільним, якщо отримані середні показники не нижчі достатнього рівня навченості 0,7 (Беспалько, 1968, с. 52). Середні коефіцієнти навченості передекспериментального, проміжного й післяекспериментального зрізів наведено в таблиці 1.

Таблиця 1

Рівні навченості експериментальних груп

\begin{tabular}{|c|c|c|c|}
\hline \multirow{2}{*}{$\begin{array}{c}\text { Експериментальна } \\
\text { група }\end{array}$} & \multicolumn{3}{|c|}{ Коефіціснт навченості } \\
\cline { 2 - 4 } & $\begin{array}{c}\text { Передексперимен- } \\
\text { тальний зріз }\end{array}$ & $\begin{array}{c}\text { Проміжний } \\
\text { зріз }\end{array}$ & $\begin{array}{c}\text { Післяексперимен- } \\
\text { тальний зріз }\end{array}$ \\
\hline $\mathrm{E} Г 1$ & 0,72 & 0,78 & 0,80 \\
\hline $\mathrm{E} Г 2$ & 0,70 & 0,75 & 0,83 \\
\hline $\mathrm{E}$ 23 & 0,71 & 0,77 & 0,80 \\
\hline $\mathrm{E} Г 4$ & 0,71 & 0,75 & 0,82 \\
\hline
\end{tabular}

Порівняльні результати (приріст) передекспериментального, проміжного й післяекспериментального зрізів по всіх експериментальних групах наведено в таблиці 2.

Таблиця 2

Порівняльні результати (приріст) по ЕГ1, ЕГ2, ЕГ3, ЕГ4

\begin{tabular}{|c|c|c|c|}
\hline $\begin{array}{c}\text { Експериментальна } \\
\text { група }\end{array}$ & $\begin{array}{c}\text { Приріст 1 } \\
\text { (передексперимен- } \\
\text { тальний - } \\
\text { проміжний зрізи) }\end{array}$ & $\begin{array}{c}\text { Приріст 2 } \\
\text { (проміжний зріз - } \\
\text { післяексперимен- } \\
\text { тальний зріз) }\end{array}$ & $\begin{array}{c}\text { Загальний } \\
\text { приріст } \\
\text { коефіцієнту } \\
\text { навченості }\end{array}$ \\
\hline ЕГ1 & 0,06 & 0,02 & 0,08 \\
\hline ЕГ2 & 0,05 & 0,08 & 0,13 \\
\hline ЕГ3 & 0,06 & 0,03 & 0,09 \\
\hline ЕГ4 & 0,04 & 0,07 & 0,11 \\
\hline
\end{tabular}


Порівняльні результати свідчать про наявний приріст у всіх експериментальних групах, однак найбільший показник виявлено в ЕГ2 $(0,13)$, а найменший - в ЕГ1 $(0,08)$. Це підтверджує наше припущення про доцільність комбінування двох варіантів експліцитних моделей на основі інструкцій «зверху-вниз» і «знизу-вверх». Найкращі показники виявлено в ЕГ2, у якій на початковому етапі навчання було застосовано варіант «зверху-вниз» 3 поступовим переходом до варіанту «знизу-вверх» на просунутому етапі навчання.

Достовірність отриманих даних було перевірено за допомогою багатофункціонального статистичного критерію - кутового перетворення Фішера $\left(\varphi^{*}\right)$, який застосовується для порівняння двох вибірок за частотою наявності ефекту шляхом переведення відсоткових часток величин центрального кута (Сидоренко, 2004, с. 158).

Саме 3 такою метою визначено відсоткові частки студентів, у яких спостерігається й не спостерігається ефект («є ефект» / «немає ефекту»), i сформульовано нульову $\left(\mathrm{H}_{0}\right)$ й альтернативну $\left(\mathrm{H}_{1}\right)$ статистичні гіпотези для кожної ЕГ за допомогою порівняння результатів перед- та післяекспериментального зрізів у кожній експериментальній групі та формулювання статистичних гіпотез - про відсутність відмінностей $\left(\mathrm{H}_{0}\right)$ та про значимість відмінностей $\left(\mathrm{H}_{1}\right)$.

Емпіричне значення $\boldsymbol{\varphi}^{*}$ підраховано за формулою:

$$
\varphi^{*}=\left(\varphi_{1}-\varphi_{2}\right) \cdot \sqrt{\frac{n_{1} \cdot n_{2}}{n_{1}+n_{2}}}
$$

На основі порівняння емпіричного значення $\varphi^{*}$ емп із критичним $\varphi^{*}$ кр побудовано «вісь значущості» на підтвердження достовірності однієї 3 висунутих статистичних гіпотез.

Аналіз результатів експериментального навчання засвідчує ефективність двох варіантів експліцитних моделей оволодіння навчальними стратегіями на основі інструкцій. Водночас, комбінування моделей, яке застосовувалося для ЕГ2, а саме використання на початковому етапі моделі «зверху-вниз» і перехід до використання моделі «знизу-вверх» на просунутому етапі, забезпечило отримання найкращих результатів в ЕГ2. Заміна моделі «знизу-вверх» на модель «зверху-вниз» в ЕГ4 також сприяла досягненню кращого результату, ніж в ЕГ1 і ЕГЗ, у яких студенти навчалися за сталими моделями протягом двох етапів навчання.

Як підсумок, комбінування експліцитних моделей вивчення англійської мови на основі інструкцій «зверху-вниз» і «знизу-вверх» сприяє ефективнішому засвоєнню й розширенню тематики навчальних $\mathrm{i}$ комунікативних стратегій вивчення англійської мови. Ефективність варіанту поступового переходу від моделі «зверху-вниз» до моделі «знизу-вверх» в ЕГ2 пояснюється тим, що низький рівень володіння стратегіями, який продемонстрували студенти першого курсу на передекспериментальному зрізі, значно підвищився після регулярного застосування моделі «зверху-вниз», яка передбачає активну участь викладача в моделюванні, поясненні, заохочуванні й оцінюванні запропонованої стратегії, що сприяє розширенню знань, навичок i вмінь користування стратегіями та урізноманітнює їх зміст, але водночас стримує розвиток студентської автономії у прийнятті рішень щодо власного навчання. Перехід до моделі «знизу-вверх» на просунутому етапі, коли рівень володіння стратегіями вивчення англійської мови у студентів зріс до середнього, сприяє зростанню 
рівня автономного навчання, оскільки модель «знизу-вверх» передбачає самостійність студента в аналізі навчальної ситуації, виборі навчальної або комунікативної стратегії, самооцінюванні, але з підтримкою викладача в аналізі результатів, зворотного зв'язку, корегуванні.

Висновки і перспективи подальших розвідок. Отже, аналіз результатів післяекспериментального зрізу демонструє сформованість професійно орієнтованої англомовної комунікативної компетентності на рівні володіння мовою В2, а також суттєвий приріст у знаннях, навичках і вміннях учасників експериментального навчання щодо рівня компетентності в автономному навчанні й рівня володіння стратегіями вивчення іноземної мови, що підтверджує робочу гіпотезу експериментального навчання, a, отже, й ефективність розробленої методики автономного навчання професійно орієнтованого англомовного спілкування майбутніх учителів математики.

\section{СПИСОК ВИКОРИСТАНИХ ДЖЕРЕЛ}

Акопова, А. \& Пшегусова, Г. (2012). Обучение иностранному языку в магистратуре. Ростов-на-Дону.

Проскурина, Г. (2015). Организация экспериментального обучения иноязычной устной деловой аргументированной речи. Вестник ИрГТУ, 5, 453457.

Штульман, Э. (1976). Методический эксперимент в системе методов исследования. Воронеж: Издательство Воронежского университета.

Гурвич, П. (1980). Теория и практика эксперимента в методике преподавания иностранных языков. Владимир: Владимирский государственный педагогический институт имени П. И. Лебедева-Полянского.

Беспалько, В. (1968). Опыт разработки и использования критериев качества усвоения знаний. Советская педагогика, 4, 52-69.

Сидоренко, Е. (2004). Методы математической обработки в психологии. Санкт-Петербург: ООО «Речь».

\section{REFERENCES}

Akopova. A. S.. \& Pshegusova. G. S. (2012). Obucheniye inostrannomu yazyku v magistrature. [Foreign language teaching in the magistracy]. Rostov-na-Donu. [in Russian]

Proskurina. G. (2015). Organizatsiya ekperimentalnogo obucheniya inoyazychnoy ustnoy delovoy argumentirovannoy rechi. [Organization of experimental teaching of foreign language oral business reasoned speech]. Vestnik IrGTU. 5. 453-457. [in Russian]

Shtulman. E. (1976). Metodicheskiy eksperiment $v$ sisteme metodov issledovaniya [Methodical experiment in the system of research methods]. Voronezh: Izdatelstvo Voronezhskogo universiteta. [in Russian]

Gurvich. P. (1980). Teoriya i praktika eksperimenta $v$ metodike prepodavaniya inostrannykh yazykov [Theory and practice of experiment in the methodology of teaching foreign languages]. Vladimir: Vladimirskiy gosudarstvennyy pedagogicheskiy institut imeni P. I. Lebedeva-Polyanskogo. [in Russian]

Bespalko. V. (1968). Opyt razrabotki $i$ ispolzovaniya kriteriyev kachestva usvoyeniya znaniy [Experience in developing and using criteria for the quality of knowledge assimilation]. Sovetskaya pedagogika. 4. 52-69. [in Russian] 
Інноватика у вихованні. Випуск 12. 2020.

Sidorenko. E. (2004). Metody matematicheskoy obrabotki v psikhologii [Methods of mathematical processing in psychology]. Sankt-Peterburg: OOO "Rech".[in Russian]

\title{
EXPERIMENTAL VERIFICATION OF THE METHODOLOGY OF AUTONOMOUS LEARNING OF PROFESSION ORIENTED ENGLISH COMMUNICATION OF PROSPECTIVE TEACHERS OF MATHEMATICS
}

\author{
Natalia Dmitrenko \\ $\mathrm{PhD}$ in Pedagogy, \\ Associate Professor at the Department of Foreign Language Teaching Methods, \\ Vinnytsia Mykhailo Kotsiubynskyi State Pedagogical University, \\ Vinnytsia, Ukraine \\ ORCID: 0000-0002-3556-0003 \\ e-mail: nataliadmitrenko0302@gmail.com
}

\begin{abstract}
The article is devoted to the problem of experimental verification of the effectiveness of the methodology of autonomous learning of profession oriented English communication of prospective teachers of mathematics. The article describes the stages of experimental training, namely: the preparatory stage, the implementation stage and the effective stage. The purpose, objectives and hypothesis of experimental learning are determined. The variable and non-varied conditions of experimental training are presented. The variable condition of experimental training is distinguished as a sequence of stages in the process of applying of two explicit models of learning strategies based on instructions «top-down» and «bottom-up» in the developed methodological system of autonomous learning of professional oriented English communication of prospective teachers of mathematics. Comparative analysis of the obtained results indicates the raising levels in all experimental groups, which confirms the assumption of the feasibility of combination of the two variants of explicit models based on the instructions «top-down» and «bottom-up» ones. Analysis of the results of the post-experimental section shows the formation of professional oriented English communicative competence at the B2 level of language proficiency, as well as a significant increase in knowledge, skills and abilities of participants of experimental training and their levels of autonomous learning competence and learning strategies acquisition. Thus, the results confirm the effectiveness of the developed methodology of autonomous learning of professional oriented English communication of prospective teachers of mathematics. The developed methodology can be recommended for implementing into educational process of higher educational establishments.
\end{abstract}

Key words: autonomous learning, professional oriented English communication, prospective teachers of mathematics, experimental learning, variable condition.

Стаття надійшла до редакиіï 11.09. 2020 p. 